\title{
Editorial
}

\section{Reivindicando a Ramazzini, siempre de actualidad}

\author{
María Castellano Arroyo
}

La buena práctica médica comienza con una buena historia clínica. La anamnesis debe recoger los datos que permitan orientar el diagnóstico hacia el proceso que ocasiona o influye en la presencia de los síntomas por los que el paciente consulta. Hipócrates en su aportación de buen clínico propuso las preguntas básicas e imprescindibles: ¿Qué le pasa?, ¿Desde cuándo? y, ¿A qué lo atribuye? De ellas se deriva una información que el buen médico ordena conforme a los síndromes y/o enfermedades concretas. La anamnesis adecuada se complementará con la exploración que en cada caso proceda y con los análisis complementarios que aporten claridad al diagnóstico diferencial y refuercen o confirmen el diagnóstico acertado. Todos los médicos estarían de acuerdo con estos principios generales, guía del buen profesional.

Bernardino Ramazzini también suscribiría lo que acabamos de decir, aunque su nacimiento se remonte al 4 de octubre de 1633, en Carpi y su muerte al 5 de noviembre de 1714, en Padova, por lo que este año celebramos en el ámbito de la Medicina del Trabajo y de la salud laboral el IV centenario de su fallecimiento.

El persistente recuerdo de su figura está vinculado a su perspicacia al relacionar el trabajo o las tareas que realizaban diversos operarios (para él artesanos), con los síntomas y patologías que manifestaban antes o después. Descubría y describía así las enfermedades profesionales, tema que, desde entonces, reclamó el interés de los médicos e higienistas de los siglos siguientes, interés que continúa en la actualidad, siendo motivo de estudio los agentes patógenos y sus mecanismos, así como las medidas de protección generales e individuales.

Su formación hipocrática y buen hacer junto al enfermo lo llevaban a aplicar sistemáticamente las preguntas hipocráticas, las cuales se le quedaron incompletas a la luz de sus observaciones personales sobre las enfermedades laborales; por eso propuso completar el interrogatorio hipocrático con la cuarta pregunta: ¿En qué trabaja?, con ella daba la oportunidad al enfermo de introducir, como elemento etiológico de sus males, los riesgos a los que estaba sometido en su actividad laboral.

Desde entonces han pasado cuatro siglos, su obra fue el germen de una especialidad, la Medicina del Trabajo, cuyos fines son inicialmente preventivos, y después diagnósticos y terapéuticos. En una organización asistencial excelente como la que disfrutamos en España, el nivel de Atención Primaria es el adecuado para detectar en sus inicios cualquier tipo de patología en cuyo origen pueda estar influyendo el trabajo a que se dedica el paciente que consulta; por ello, el tener presente a Ramazzini en su pregunta ¿En qué trabaja? debe seguir teniendo toda la actualidad e importancia que se merece.

Traemos este tema a colación porque guarda relación con un acontecimiento médico que nos ha conmocionado a todos, la infección por el virus Ébola y, en concreto, su extensión a España.

La primera paciente contagiada entre nosotros Teresa Romero, el mecanismo de su contagio, la agilidad y diligencia con que se produjo el diagnóstico, las actuaciones posteriores tras la sospecha de que podía tratarse de esta infección, hasta que se produjo 
el adecuado encarrilamiento de los procedimientos a seguir, son temas que han generado muchas palabras habladas y escritas.

Uno de esos temas fue, si la paciente al consultar en Atención Primaria a su médico comunicó o no el antecedente personal de haber estado en contacto con enfermos de Ébola.

Sin entrar en la realidad de lo que sucedió en aquella consulta hemos de preguntarnos ¿a Bernardino Ramazzini se le habría escapado este dato si, de acuerdo a su propuesta y recomendación, después de preguntar ¿Qué le pasa? y, ¿Desde cuándo?, hubiera seguido preguntando ¿A qué lo atribuye y en qué trabaja?. Es altamente probable que este interrogatorio sistemático y completo habría estimulado en la paciente el reconocimiento de la importancia de su trabajo en los días anteriores, y en la médico que la atendía la oportunidad de contar con más datos y de un valor real, para extender el diagnóstico a posibilidades diferentes de las observadas en la rutina diaria.

Al profesor Antonio Campos, antiguo director del Instituto de Salud Carlos III, le gusta recordar la frase que dice: "En Medicina lo más frecuente es siempre lo más frecuente", y, en efecto, es un buen aforismo médico que hay que tener presente porque su contenido se suele cumplir. Sin embargo, introducir en la anamnesis de un paciente la pregunta ¿En qué trabaja?, y yo aún añadiría ¿Qué sustancias o materiales maneja?, son preguntas que abren una puerta a posibilidades insospechadas para el médico que, a veces se olvida, de los efectos de las sustancias químicas, entre las que pueden estar los disolventes, los plaguicidas o los metales y muchos más, o agentes físicos y, desde luego, los biológicos.

En este año de especial recuerdo a Bernardino Ramazzini, por los médicos del Trabajo, creo que todos los médicos podemos tomar de él esta recomendación tan sencilla, pero que aún no tenemos incorporada en la anamnesis que dirigimos a nuestros pacientes en las visitas rutinarias ¿En qué trabaja usted? y si añadimos ¿Qué sustancias o materiales maneja?, ampliaremos las posibilidades de información. Son preguntas simples que abren oportunidades diagnósticas que pueden escaparse desde una perspectiva rutinaria de la historia clínica.

Si actuamos así haremos presente a Bernardino Ramazzini en aras de una mejor medicina. 